\title{
An Outbreak of Cerebrospinal Fever in a 19th Century British Mediterranean Naval Base
}

\author{
Dr C Savona-Ventura \\ MD, MRCOG
}

Department of Obstetrics and Gynaecology, St. Luke's Hospital, MALTA

SUMMARY: Epidemic Meningococcal meningitis first made its definite appearance in Europe in the beginning oof
the nineteenth century. The first recorded epidemic in the Maltese Islands, which straddled the sea-routes of the
Mediterranean, occurred in the late nineteenth century. This paper describes a manuscript report prepared at the
request of the Lieutenant Governor regarding this epidemic in the light of the contemporary knowledge about the $\hat{E}^{2}$
infection.

\section{Introduction}

Meningococcal meningitis, previously referred to as Cerebrospinal Fever, was recognised as a serious menace to health at the beginning of the nineteenth century, and it is possible that epidemic meningococcal disease is a relatively new condition. Cerebrospinal fever was first recorded as an epidemic in Geneva by $\mathrm{G}$ Vieusseux in 1805 , and in the following year was reported from Medfield, Massachusetts by Danielson and Mann. During 1806-07 it attacked the Prussian Army. A classic treatise is that published in New York by Elisha North in 1811, wherein he referred to the disease as "spotted fever". This description may have in fact contributed to this disease being confused with petechial typhus, a confusion that hampered further progress until the mid-nineteenth century. It is possible that epidemic meningococcal disease is a relatively new condition since, because of the characteristic features of the disease, it seems unlikely that epidemics would have remained unreported had they occurred at an earlier date. However D J Plazak has found a report indicating that an epidemic of meningitis may have affected the Sault Ste. Marie Indians of Michigan as far back as 1670 (1). The disease made its appearance in North Africa in 1840 as an epidemic among French troops stationed in Algeria. Other reports came from southern Italy, Denmark, Ireland, Germany and the USA. Reports of the disease emanated from Sweden, Germany and Russia in the 1860 s and 1870 s. The disease was particularly virulent during the American Civil War (1861-1877), while other epidemics were reported from Asia and Africa (1). It appears that the disease has, in fact, shown a gradual increase, both in its geographical range and in the number of persons it attacked. From 1805 to 1830 the disease was most prevalent in the United States; from 1837 to 1850 France was attacked most severely; from 1854 to 1874 epidemics occurred both in Europe and in America; and from 1875 onwards not only these two continents but Asia, Africa and Australia had been invaded (2) .

By 1886 it was known that meningitis might be caused by an organism indistinguishable from the pneumococcus.

The causative organism for meningococcal meningitio was identified as Neisseria meningitides by Weichselbaum of Vienna in 1887. Weichselbaur reported finding in six post-mortem cases "an entirel different kind of bacteria". In stained films of meningitie exudate and ventricular fluid he found a moderate numbes of cocci which "remind one of gonococci". He cultivated the organism on nutrient agar, confirmed that large dosefs could kill experimental animals, and identified the staining properties of the organism. He named the cocti "Diplococcus intracellular meningitidis" (ब) Weichselbaum's findings were not confirmed until 1 क्षे when Jager reported the presence of similar diplococce twelve cases of epidemic meningitis in Stuttgart. Thus it was only by 1896 that the basic facts relating to 8 (n) bacteriology of meningitis were accepted, though tiere was still considerable obscurity concerning epidemiology of the disease. This was rectified in 1 क when W J Councilman, F B Mallory and J H Wrigh published their investigation of the 1896-97 meningitio outbreak in Boston (4). Their monograph gives a full an\& excellent account of the epidemiology, clinical feature $\vec{p}$ morbid anatomy and bacteriology of the disease. Little was added to their contribution until the studie undertaken during the First World War (5).

Meningococcal meningitis is now known to be cause by Neisseria meningitidis of groups, A, B, C, D, X, Y, 䂞 $\mathrm{W} 135$ and $29 \mathrm{E}$, of which $\mathrm{A}$ and $\mathrm{B}$ are the commonest The meningococcus lives as a parasite in the nasopharyn $\$$ and in non-epidemic times the meningococcus is presen in 2-8 percent of healthy civilians. Relatively few develog disease. The carrier rate increases tenfold prior to ap. epidemic. Infection is transmitted by droplets, and man $\$$ factors probably play a role in determining clinical illnes including prior immunity, physical stress, ang immediately antecedent viral infections. The development of meningococcal disease is favoured by complement deficiencies especially C7-C9. Disease caused by this meningococcus ranges from an inapparent infection of the nasopharynx to the fulminating Waterhouse-Friderichse⿰彳 syndrome characterized by circulatory shock and collaps $\tilde{\omega}$ proving fatal within a few hours. In between come $\mathbb{9}$ 
number of different clinical manifestations, the commonest being an acute purulent meningitis (2).

\section{History of Disease in Maltese Islands}

The first mention of Cerebrospinal fever on the Maltese Islands, situated in the central Mediterranean, dates to the year 1887 when a number of cases and deaths were reported and attracted the attention of local medical men and the local administrative authorities. About that year, the disease was epidemic in almost all the countries bordering on, and in the islands of the Mediterranean, and the infection was no doubt imported from one or other of the affected places (6). The fortnightly reports on the "Statement of Mortality in Malta and Gozo for 1887", indicate that four deaths attributed to cerebrospinal fever occurred in the rural village of Sannat in Gozo during the period from 1 March to 15 May (Table 1). No further details about this epidemic can be obtained from published sources, however, a detailed description of the outbreak identified as one of "Cerebro Spinal Meningitis" can be found in one of the correspondence books for Victoria Hospital in Gozo (8). The report, dated 31 May 1887 and about eight and a half pages long, was prepared at the verbal request of the Lieutenant Governor by Dr B Mercieca, Medical Superintendent for Victoria Hospital, and addressed to Mr P Trapani, Assistant Secretary to Government in Gozo. Dr Mercieca was assisted in the preparation of the report by Drs G Debono and N Tabone, Professors G O Galea and S L Pisani, and the Army Surgeons Drs Reed and Coats. The outbreak as described in the report made its appearance in February and affected at least seven individuals of the same family, of whom only the youngest two survived (Table 1).

The report starts by attempting to identify the aetiology of the disease, howver Dr Mercieca reported that "As it is the case with other countries, no satisfactory result whatever has been arrived at in Gozo, as to the cause of the disease. The spot where the cases broke out was inspected; the food and water used by the patients was examined, as also their external relations etc but all to no avail. When the disease broke out the general state of health in the island was very good: and no epidemic prevailed at the time". While postmortems had been

Table 1

1887 Gozo Epidemic - Case (7,8)

\begin{tabular}{|c|c|c|c|c|c|c|}
\hline \multirow[t]{2}{*}{$\begin{array}{l}\text { Clinical } \\
\text { Type }\end{array}$} & \multicolumn{3}{|c|}{$\begin{array}{c}\text { Fortnightly Mortality } \\
\text { Reports }\end{array}$} & \multicolumn{3}{|c|}{$\begin{array}{c}\text { Manuscript } \\
\text { Report }\end{array}$} \\
\hline & Sex & Age & Date of death & Sex & Age & Date of death \\
\hline 1. Acute & M & $25-35$ & $1-15 / 3 / 1887$ & \multirow{3}{*}{\multicolumn{3}{|c|}{$\begin{array}{l}\text { Three died of the disease } \\
\text { under this form and their } \\
\text { ages were between } 18 \\
\text { and } 27\end{array}$}} \\
\hline 2. Acute & $\mathrm{F}$ & $15-20$ & $1-15 / 3 / 1887$ & & & \\
\hline 3. Acute & $?$ & $?$ & $?$ & & & \\
\hline 4. Chronic & & $25-35$ & $1-15 / 4 / 1887$ & $\mathrm{~F}$ & 22 & $4 / 4 / 1887$ \\
\hline 5. Chronic & & $45-55$ & $1-15 / 5 / 1887$ & $F$ & $?$ & $7 / 5 / 1887$ \\
\hline 6. Chronic & & $?$ & $?$ & $?$ & 8 & survived \\
\hline 7. Chronic & & $?$ & $?$ & $?$ & 13 & survived \\
\hline
\end{tabular}

performed as part of the investigation of the outbreak, the report fails to mention any microscopic studies on the cerebral exudate (8). The first experiments with the microscope in Malta were recorded by G Gulia, Professor of Legal Medicine in 1871, though microscopic examination of organs removed at autopsy was carried out at the Military General Hospital in 1860 and probably earlier $(9,10)$. By 1887 bacteriology on the Maltese Islands was a well established branch of medical investigation. In 1887 Dr David Bruce and Dr G Caruana Scicluna prepared paraffin section of spleen tissue from soldiers dying from Malta Fever and identified the Brucella melitensis organism. In the same year the same workers confirmed the association of Koch's comma spirillum with cholera $(11,12)$. While microscopy studies were common in the main island Malta, the investigative procedure was however unlikely to have been available for use in the study of the 1887 outbreak in smaller island of Gozo since the hospital there was a peripheral one.

The outbreak, as described, was one of a severe nature with evident signs of meningitis. The progress of the disease was described "under two forms: vir - one acute or fulminant - (Meningite foudeyan Niemeyer), and the other intermittent (Niemeyer) and of long duration". The characteristic features of the illness appeared to be fever, chills, headaches, neck pain, nausea and vomiting. Then convulsions which occurred resulted in nuchal and back rigidity, with unconsciousness and death ensuing. One chronic patient developed an ophthalmic complication in that "her eyeballs became much ignited, symptoms cameo in; suppuration followed, which ended in the totat destruction of the eye-balls and complete blindness". Ato postmortem, large haemorrhagic spots were noted, while dissection of the cerebral structure showed hyperaemia, an adherent opaque arachnoid membrane, and exudation in the subarachnoid space with haemorrhages in the cerebral convolutions (8). The clinical and pathological features fit in with those described for meningococcal meningitis (2). Dr Mercieca and his helpers appear to have been familiar with the literature relating to the disease, while the Army surgeons Drs Reed and Coats were further familiar with the disease because of their previous experience in the epidemic occurring in Dublin (Ireland) (8). The description uses the same classification as that given in the reports of $\mathbf{J}$ Burdon-Sanderson published by the New Sydenham Society (13). Copies of the said Society's publications are in the holding of the Malta Medical School Library, while D Bruce seems to have derived his knowledge of bacteriology techniques from the New Sydenham Society 1886 publication Microparasites in Disease which consisted of English translations on many papers by Koch and his pupils (5).

The treatment used in the 1887 Gozo epidemic followed the suggested modalities in the literature being 'generally reconstituent and sedative - Broth, Beef-tea \& Portwine were given in large scale. At the outbreak of the disease, aperients and cold lotions on the head were 
prescribed. Afterwards sedatives such as opium and chloral hydrate, but the best results were attained through hypodermic injection of morphia". In spite of the efforts of the medical practitioners, the mortality rate reached $71 \%$ (8). The contemporary literature reported the narcotics to be the most effective therapy, though in New York potassium bromide was favoured. The prognosis of the disease was reported to be generally bad with a mortality of $20-40 \%(13,14)$.

The 1887 Gozo outbreak of Cerebrospinal meningitis appears to have been considered an isolated occurrence by subsequent health authorities, since until 1916 no cases of the disease were further reported among the local population, the one or two cases reported being actually imported or occurring among the military servicemen (6). The first significant outbreak in Malta of cerebrospinal meningitis confirmed by bacteriological studies occurred in March 1916. This outbreak started in the residences of two Malta Militia privates spreading to the population affecting 12 individuals with three deaths. Other nontypical cases may have occurred but were not diagnosed as such. The 1916 outbreak was confined to five villages in Malta - Naxxar, Zabbar, Zejtun, Tarxien, and Ghaxaq by isolation of patients and contacts, the disinfection of clothes, bedding and houses, and house to house inspections in the affected regions to ensure a standard of hygiene $(6,15)$. After this outbreak, meningococcal meningitis appears to have become endemic with cases being reported in the civilian population nearly every year (Fig 1).

\section{Discussion}

The relatively late introduction of endemic Cerebrospinal meningitis to the Maltese Islands is surprising in view of the special situation of the islands throughout the nineteenth century. Situated in the Central Mediterranean, the Islands straddled the sea-routes. Seaborne trade had grown rapidly in Malta from the early 1850 's as the general tempo of Mediterranean commerce had amplified. The Peninsula and Orient Line, for Incidence per 100,000 pop.

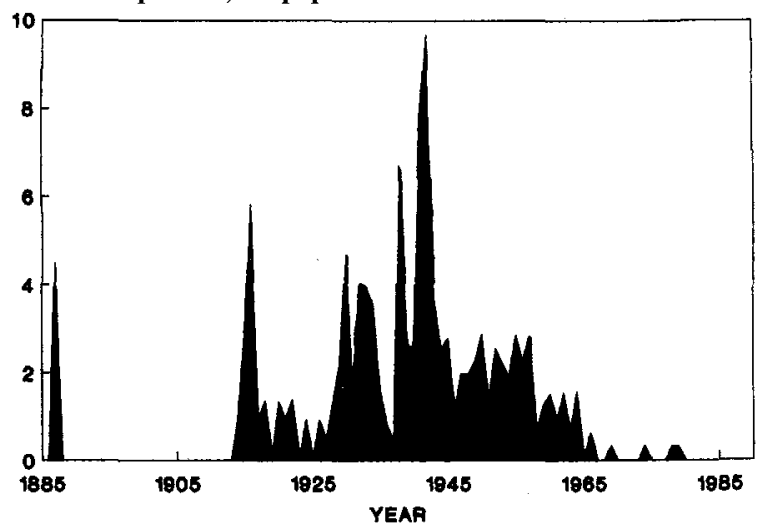

Fig 1: Incidence: Cerebrospinal Fever example, carried increasing quantities of traffic througk the Mediterranean and in 1858 the company opened railway route which linked Alexandria to the Suez, thu\& facilitating the transport of goods and passengers acros尺 the neck of land which separated the Mediterranean fromo the Red Sea. The Suez Canal, which came in operation in? 1869, further strengthened this link. After 1869 there was a rapid rise in the number of ships calling at the Grand Harbour, and in 1880 Malta was firmly established as th chief coaling station for vessels plying between Britain $\overline{\bar{p}}$ India and the East (16). In addition, contacts wer maintained by the civilian population with North Africa since emigrating Maltese went principally to these lands? By the end of the nineteenth century there were well oveP 50,000 Maltese living around the shores of the Mediterranean, particularly in Algeria, Tunis, Tripoli an Egypt (16). Cerebrospinal meningitis was eventuall introduced to become an endemic disease in the earl twentieth century. It was not the only disease which was introduced to the Islands. The continued naval ans military contact allowed the introduction of a number od epidemic infections to the Islands, which however were controlled. Typhus, introduced to the Islands on a number of occasions in the late nineteenth and early twentietto century, eventually became endemic after the 1904 epidemic (17).

The risk of introduction of epidemic infections to Maltese Islands required the British Naval, Military 角里 Civil authorities to undertake rigorous efforts to contot and manage infectious disease. The 1887 Report reflets the active investigative efforts which were moted whenever an epidemic threatened the population ande⿶ie British garrison. The investigation was initiated by thes Lieutenant Governor who was responsible to the Colonia Office for the administration of Gozo. The Britis Admiralty nominated two commissioned officers of the British Medical Service - Drs Reed and Coats - both o whom had previous experience with the disease in previous epidemic in Dublin (8). The only medical officef with the surname Coats who held a commission with the British Army at the end of the nineteenth century was $\underset{\text {. }}{ }$. James Coats who was born on 24 July 1848 and qualifie MD with honours from Glasgow in 1869. He was appointed Staff Assistant Surgeon on 1 April 1871థ becoming Surgeon-Major on 1 April 1883, and Surgeon Lieutenant-Colonel on 1 April 1891. He was put of retired pay on 15 April 1896, during which time he waș. employed at Ayr until 5 July 1909. There appears to be ne medical officer by the name of Reed commissioned wit the British Medical Service during the period, though $\$$ number of officers with the surname of Reade and Reis have been listed (18).

The Civil Government was represented by five doctors Dr B Mercieca, the author of the report, was the Medical Superintendent to Victoria Hospital in Gozo, Dr 80 Tabone was the Resident Medical Officer to the Hospitd eventually becoming Medical Superintendent, while Dr 
Debono was the District Medical Officer for the capital city of Gozo. These doctors were helped in their investigation by two Professors of the University of Malta. G O Galea was the Professor of Medicine of the University, while Professor S L Pisani was at the time of the investigation the Chief Government Medical Officer, Pisani was born on 27 May 1828 and qualified from the University of Malta in 1850 and from the Edinburgh Medical School in 1853. He volunteered to serve as a surgeon with the British Army in the Crimean War, returning to Malta in 1855 . He was appointed professor by the University of Malta to the Chair of Anatomy and Histology (1858-76), of Midwifery and Gynaecology (1858-69) and of Surgery (1869-85). In 1885 he was appointed to the post of Chief Government Medical Officer, a post he retained until 1902. His publications include an exhaustive report on the cholera epidemic of 1887 which reports the isolation of the bacillus by Dr J Caruana Scicluna and D Bruce $(8,19)$.

The necessity of controlling infective disease, particularly whenever epidemics threatened or broke out among the local population, resulted in a continuous drive in the late nineteenth century to understand the aetiology and clinical course of infective disease. This resulted in investigations of endemic infectious disease such as Malta Fever and Kala Azar, and epidemic outbreaks of Cholera (1887) when D Bruce and J Caruana Scicluna confirmed the association of Koch's comma spirillum with cholera, and the typhoid epidemic (1892) when Dr M L Hughes demonstrated the typhoid bacillus in all the fatal cases of the disease $(10,11,12)$. The interest of the British administrators was primarily financial as evident by the attitude reported towards Malta Fever. "This fever was seriously undermining the strength of the twenty-five thousand soldiers and sailors of the Mediterranean. In fact, in 1891, it was calculated that the Malta garrison was costing the State, on account of the disease alone, an expense equal to that of a whole regiment one thousand strong in hospital for twenty-five days" (20).

\section{REFERENCES}

1. ACKERKNECHT E H. History and disease of the most important disease. New York, Hafner Publ Co: 1965, p84-85.

2. Wilson G, Miles R, Parker M T. Topley and Wilson's Principles of bacteriology, virology and immunity. London: E Arnold: 1984, Vol 3, p 370377.

3. Weichselbaum A. Ueber die Aetiologie der akuten meningitis cerebro-spinalis. Fortschr Med 1887; 5: 573.

4. Councilman W T, Mallory F B, Wright J H. Epidemic Cerebrospinal Meningitis and its relation to other forms of meningitis. Boston, 1898.

5. Foster W D. A History of Medical Bacteriology and Immunology. London, Heinemann Med Books Ltd., 1970, p 86-90.
6. Bernard A V. Notes on Cerebro-Spinal fever in Malta. Report on the Health of the Maltese Islands during 1916-17. Malta Government Gazette supplement, 16 November 1917, 25: p 265.

7. Statement on Mortality in Malta and Gozo. Malta Government Gazette, 1887, p 218-219, 242-243, 285286. Fortnightly report.

8. Correspondence Book for Victoria Hospital for period 9 February 1886 to 26 February 1889 . Manuscript in author's possession. Letter 130, fol. 121-129.

9. CASSAR P. Landmarks in the development of forensic medicine in the Maltese Islands. Malta, M U P, 1974, p 31.

10. Cassar P. Medical History of Malta. (London), Wellcome Hist Med Libr, 1964, p 240-247, 264-265, 267, 539-543.

11. BRUCE D. Note on the discovery of a micro-organism in Malta Fever. Practitioner 1887; 39: 161.

12. PISANI S L. Report on the Cholera epidemic in the year 1887. Malta, Government Printing Office, 1888, p 6, 18.

13. ANSTIC E. Report on the progress of physiology ando the allied sciences during the years 1865 and 1866 . Biennial retrospect of Medicine, Surgery and theie allied sciences for 1865-6. London, New Sydenhane Soc, 1867, p 55-62.

14. POWER H. Report on the progress of physiology an $\$$ the allied sciences during the years 1873 and 1874 . Biennial retrospect of Medicine, Surgery, and the allied sciences for 1873-4. London, New Sydenham Soc, 1875, p 61-62.

15. Caruana Scicluna G. Annual Report for the Public Health Department. Reports on the working of Government during the financial year 1915-16. Malta,Government Printing Office, 1917. Sec I, p 3, $6,12,17,40$

16. Blouet B. The story of Malta. Malta, Progress Press, 1989, p 166-167, 171.

17. Savona-Ventura. C. Malta and the British Navy: the medical connection during the nineteeth century. Part III. Medical and other problems. J R Nav Med Serv 1993; 79: 100-105.

18. Peterkin A, Johnston W. Commissioned Officers in the Medical Services of the British Army 1660-1960. London, Wellcome Hist Med Libr., 1968, Vol I, p 478, 597, 627.

19. Cassar P. Profile: Professor Salvatore Luigi Pisani M D (1828-1908). Malta Today 3/1982; 17: 14-16.

20. Hughes M L. Note on the Endemic Fever of the Mediterranean Medico-Chirurgical Transactions, 1896; p 45. 